\title{
Survey of Environmental Attitudes: Implications to Sustainable Waste Management
}

\author{
CHRISTIAN D. MAGDALE \\ ORCID No. 0000-0003-4346-2240 \\ magdalechristian @gmail.com \\ JUDY MARIE R. ZOLETA \\ ORCID No. 0000-0002-8251-6822 \\ zjudy_msuiit@yahoo.com.ph \\ Liceo de Cagayan University \\ Cagayan de Oro City, Philippines
}

\begin{abstract}
The study on environmental attitude was conducted to assess the environmental attitude of college instructors and students in Liceo de Cagayan University main campus to be used as basis for sustainable solid waste management. The study employed the descriptive method utilizing a survey questionnaire adapted from Tentawi et al., and distributed randomly to selected faculty members and students from the different colleges. Five - category responses based on the Likert scale were the basis for obtaining data. The frequency and mean were obtained. The mean values were translated into their descriptive measures. Results showed that there are more 'stronger agreements' from the teachers than from the students indicating that they exhibit stronger environmental attitude. Out of the ten (10) items found in the survey questionnaire, four (4) responses expressed neutrality indicating a lack of awareness and environmental concern on the part of the students. This may imply that students have a low degree of connectedness to the environment. Their agreements equally come from both ecocentric and egocentric stand points. The results entail exerting more effort in intensifying environmental awareness especially among students, creating committees and policy formulation within the institution.
\end{abstract}

Keywords: Environmental attitudes, sustainable waste management 


\section{INTRODUCTION}

Environmental attitude is a general opinion or feeling of someone toward his or her environment (Uyeki and Holland, 2000). Milfont (2007) viewed it as a psychological tendency expressed by evaluating the natural environment with some degree of favor or disfavor. In short, the type of attitude exhibited by an individual predicts his behavior toward the environment. The interactions between people and their environment appear to be as old as the human civilization. The hindrance of managing those interactions has been magnified by the increases in the rate, scale, and complexity of the said interactions. In general, humans have encountered the dilemma between industrialization and the conservation of the natural environment. Pollution, for example, was just considered as a local temporary event before, but it is now being deemed as an international issue. Hence, the obvious challenge now of mankind is how to promote sustainable development by having a lasting waste management, which can potentially help lower the degree of pollution. The said challenge can be possibly achieved by having proper environmental attitudes, which can lead to the right environmental behavior. Moreover, better decisions and policies can be made if one is equipped with the proper environmental behavior (Gatersleben, 2002).

This study generally seeks to determine the environmental attitudes of the students and college instructors of Liceo de Cagayan University. The determination of the environmental attitudes was anchored on two primary theories of moral responsibility regarding the environment: egocentrism and ecocentrism.

Egocentrism (self-centered) supports the view that only human beings are morally significant organisms and have direct moral standing. It assumes that the human race is and should be the master of nature and that the Earth and its resources exist for the benefit and pleasure of mankind. This is reinforced by the work ethic, which dictates that humans must be preoccupied by creating continual change. Moreover, it maintains that things that are bigger, better, and faster represent progress. In the egocentric view, nature has only instrumental value. This means that the environment is valuable only inasmuch as humans can economically use it (Enger and Smith, 2002).

Meanwhile, the theory of ecocentrism maintains that the environment deserves direct moral consideration. It does not support the idea that the environment is merely derived from human interest. It promotes the view that the environment has direct right and has inherent worth. Hence, the environment is deemed to be as important as the human beings. This view has been widely advocated by 
environmentalists (Enger and Smith, 2002).

According to Franzen and Meyer (2010), proper environmental attitudes may be associated to proper environmental behaviors, which can be used as implications of sustainable waste management. Thus, if the students and college instructors of Liceo de Cagayan University possess the right environmental attitudes, it is very likely that waste management in the campus can be sustained. There are actually many factors or situations that can hamper the effective practice of waste management in the campus. One of those factors is lack of discipline on waste disposal. It has been observed that many students in the campus throw their wastes everywhere instead of throwing them into the designated garbage bin. Other factors are the absence of clear policy formulation and the absence of intensive information dissemination on the proper waste disposal methods. Several social scientists have actually concluded that unless children develop a sense of respect and caring for the environment during their early years, they are at risk of never developing such attitudes later in life (Stapp, 1978; Tilbury, 1994; Wilson, 1994). Moreover, college instructors are on the front line in disseminating pieces of information. In addition, they also have the function of inculcating values and proper environmental attitudes in their students so that the latter can have the proper behavior toward their surrounding or environment. Thus, college instructors play an indispensable role in influencing the students' attitude. According to Ramsey and Hugerford (1989), it is necessary that teacher training program should be designed in such a way that it can equip teachers with the skills of instilling positive attitude towards environment through different subjects. This requires that teachers themselves should have positive attitude towards the environment to manifest responsible environmental behavior. Milfont (2007) emphasized the necessity to investigate whether the teachers, who are disseminating the knowledge, are equipped with environmental attitude and the behavior towards environment so that they may shape up the behavior of their students."

In a study conducted by Thornton (2009), it was found out that most of the student respondents exhibited egocentric behavior. The respondents generally agreed that nature is valuable in itself because of the benefits it provides for human use. Moreover, in another study on environmental attitudes with primary and secondary students in Asian cities, it was found out that most of the respondents claimed that they would feel sad it the environment is destroyed. The results of this study can be used for the formulation of school policies by the school administration for the promotion of sustainable waste management. 


\section{OBJECTIVES OF THE STUDY}

The study determined the environmental attitudes of faculty and students and compared the attitudes of students and teachers from the standpoint of ecocentric and egocentric views.

\section{FRAMEWORK}

This study was anchored on the theory of Milfont and Duckitt (2007) which stresses man's degree of connectedness with nature that influences his environmental attitude. The determination of the environmental attitudes was anchored on two primary theories of moral responsibility regarding the environment: egocentrism and ecocentrism as posited by Enger and Smith (2002). Egocentrism (self-centered) supports the view that only human beings are morally significant organisms and have direct moral standing. It assumes that the human race is and should be the master of nature and that the Earth and its resources exist for the benefit and pleasure of mankind. This is reinforced by the work ethic, which dictates that humans must be preoccupied by creating continual change. Moreover, it maintains that things that are bigger, better, and faster represent progress. In the egocentric view, nature has only instrumental value. This means that the environment is valuable only inasmuch as humans can economically use it. The study of Wining and Ebreo (1992) supported this by claiming that ecocentric attitudes were predictive of recycling behavior after a follow-up recycling program was implemented. This is reinforced by Thompson and Barton (1994) who posited the relationship between ecocentric attitude and observed measure of environmentally relevant behavior.

Desa et al. (2014) stressed that it is out of man's ignorance that he considers certain things as waste and other thing as useful which may imply that higher population growth may not necessarily lead to environmental degradation due to the presence of waste. The study further stresses that attitudinal problems, lack of enforcement, lack of monitoring and lack of understanding of environmental responsibilities were identified as some of the causes of improper management of waste. Hence, this study will expectedly determine the environmental attitude of students and teachers in Liceo de Cagayan University main campus. In turn, the said results will help to figure out also the proper way of addressing the problem on waste management in a sustainable manner. 


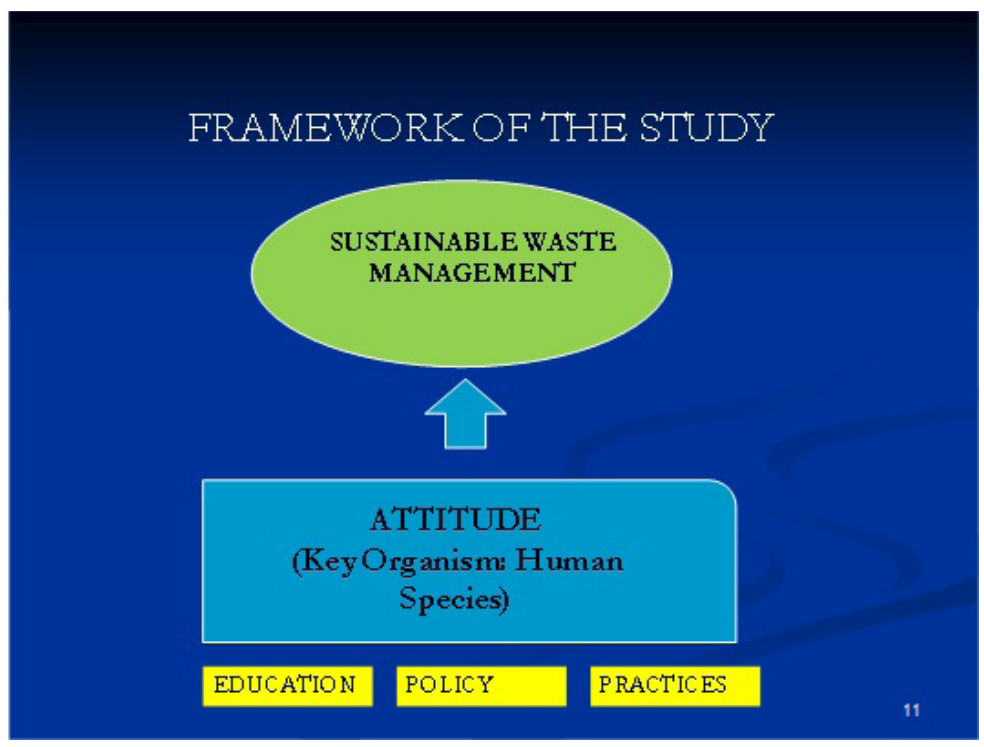

Figure 1. The Framework of the Study

\section{METHODOLOGY}

\section{Respondents}

The respondents of the study were the 250 randomly - selected college students and 70 college instructors of Liceo de Cagayan University.

\section{Tools}

The study employed environmental attitude scale. The said scale consisted of ten statements that were intended to capture the students' concern about environment. The 5-point Likert Scale ranging from Strongly Disagree to Strongly Agree was utilized to measure the degree of agreement or disagreement to each statement in the survey questionnaire. The items were selected from the scale used by Tantawi et al., (2007).

\section{Procedure}

The questionnaires were administered to 250 randomly - selected college students and 69 college instructors of Liceo de Cagayan University. For analysis of data, the mean of the responses was computed. The t-test was likewise 
used for the determination of the significant difference between the students' environmental attitude and those of the college instructors.

\section{RESULTS AND DISCUSSION}

\section{Objective 1. To find out the environmental attitude of students at the LDCU main campus}

Table 1. Frequencies and Mean Values of

Environmental Attitudes of Students

\begin{tabular}{|c|c|c|c|c|c|c|c|c|}
\hline \multirow[b]{2}{*}{ Questions } & \multicolumn{5}{|c|}{ Frequency } & \multirow[b]{2}{*}{ Total } & \multirow[b]{2}{*}{$\mathbf{x}$} & \multirow[b]{2}{*}{$\begin{array}{l}\text { Descriptive } \\
\text { Measures }\end{array}$} \\
\hline & $\begin{array}{c}\text { Strongly } \\
\text { Disagree } \\
1\end{array}$ & $\begin{array}{c}\text { Disagree } \\
2\end{array}$ & $\begin{array}{c}\text { Neither } \\
\text { Agree } \\
\text { Nor } \\
\text { Disagree } \\
3\end{array}$ & $\begin{array}{c}\text { Agree } \\
4\end{array}$ & $\begin{array}{c}\begin{array}{c}\text { Strongly } \\
\text { Agree }\end{array} \\
5\end{array}$ & & & \\
\hline $\begin{array}{l}\text { 1. One of the best things } \\
\text { about recycling is that it } \\
\text { saves money. }\end{array}$ & 7 & 7 & 9 & 91 & 136 & 250 & 4.37 & $\begin{array}{l}\text { Agree } \\
\text { Ego }\end{array}$ \\
\hline $\begin{array}{l}\text { 2. Nature is important } \\
\text { because of what it } \\
\text { can contribute to } \\
\text { the pleasure and } \\
\text { welfare of humans. }\end{array}$ & 7 & 2 & 14 & 70 & 157 & 250 & 4.47 & $\begin{array}{l}\text { Agree } \\
\text { Ego }\end{array}$ \\
\hline $\begin{array}{l}\text { 3. One of the most } \\
\text { important reasons to } \\
\text { keep lakes and rivers } \\
\text { clean is so that people } \\
\text { have a place to enjoy } \\
\text { water sports. }\end{array}$ & 14 & 24 & 76 & 84 & 52 & 250 & 3.54 & $\begin{array}{l}\text { Agree } \\
\text { Ego }\end{array}$ \\
\hline $\begin{array}{l}\text { 4. The benefits of } \\
\text { modern consumer } \\
\text { products are more } \\
\text { important than the } \\
\text { pollution that results } \\
\text { from their production } \\
\text { and use. }\end{array}$ & 65 & 55 & 52 & 59 & 19 & 250 & 2.65 & $\begin{array}{l}\text { Neither } \\
\text { agree nor } \\
\text { disagree }\end{array}$ \\
\hline 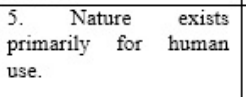 & 23 & 40 & 54 & 82 & 51 & 250 & 3.39 & $\begin{array}{l}\text { Neither } \\
\text { agree nor } \\
\text { disagree }\end{array}$ \\
\hline $\begin{array}{l}6 \text {. It makes me sad to } \\
\text { see natural } \\
\text { environments destroyed. }\end{array}$ & 9 & 3 & 7 & 31 & 200 & 250 & 4.64 & $\begin{array}{l}\text { Strongly } \\
\text { agree } \\
\text { Eco }\end{array}$ \\
\hline $\begin{array}{l}\text { 7. Nature is valuable for } \\
\text { its own sake. }\end{array}$ & 9 & 16 & 54 & 80 & 91 & 250 & 3.91 & $\begin{array}{l}\text { Neither } \\
\text { agree nor } \\
\text { disagree }\end{array}$ \\
\hline $\begin{array}{l}\text { 8. Humans have the } \\
\text { right to damage the } \\
\text { environment just to get } \\
\text { greater economic } \\
\text { growth. }\end{array}$ & 171 & 42 & 12 & 15 & 10 & 250 & 1.60 & $\begin{array}{l}\text { Disagree } \\
\text { Eco }\end{array}$ \\
\hline $\begin{array}{l}\text { 9. Despite our special } \\
\text { abilities, humans are } \\
\text { subject to the laws of } \\
\text { nature }\end{array}$ & 5 & 6 & 61 & 114 & 64 & 250 & 3.90 & $\begin{array}{l}\text { Neither } \\
\text { agree nor } \\
\text { disagree }\end{array}$ \\
\hline $\begin{array}{l}\text { 10. Plants and animals } \\
\text { have as much right as } \\
\text { humans to exist. }\end{array}$ & 6 & 10 & 37 & 52 & 145 & 250 & 4.28 & $\begin{array}{l}\text { Agree } \\
\text { Eco }\end{array}$ \\
\hline
\end{tabular}


Table 1 presents the frequencies and mean values of environmental attitudes. The mean values of the results were contrasted to a range of widely accepted values. In that range of values, $4.50-6.00$ is for strongly agree; $3.50-4.49$ is for agree; $2.50-3.49$ is for neither agree nor disagree; $1.50-2.49$ is for disagree; and $1.00-1.49$ is for strongly disagree.

Based on the results, the respondents agreed (mean value of 4.37) that one of the best things about recycling is that it saves money. This response is of egocentric nature. This can simply mean that the student respondents have been motivated to practice recycling by personal gain. Meanwhile, the respondents generally agreed (mean value of 4.47) also that nature is important to them because of what it can contribute to the pleasure and welfare of humans. This means that the students value nature simply because of the benefits that they can derive. This response can also be linked to egocentric attitude. It was also found out that the student respondents agreed (mean value of 3.54) that one of the most important reasons to keep lakes and rivers clean is so that people have a place to enjoy water sports. This is again an egocentric attitude since they consider the environment valuable only because of the enjoyment that they can get (Enger and Smith, 2002). However, they neither agreed nor disagreed (mean value of 2.65) about the idea that the benefits of modern consumer products are more important than the pollution that results from their production and use. In addition, they also neither agreed nor disagreed (mean value of 3.39) about the statement that nature exists primarily for human use.

Interestingly, most of the student respondents strongly agreed (mean value of 4.64) about the idea that they would become sad to see the environments destroyed. This response can be viewed as reflective of an ecocentric attitude as they manifest care to the environment. As to the idea that nature is valuable for its own sake, they did not agree nor disagree (mean value of 3.91). The respondents disagreed (mean value of 1.60) that humans have the right to damage the environment just to get greater economic growth. This response is of ecocentric nature as it tends to promote nature conservation. Furthermore, it can likewise indicate that the respondents are still keen on preserving the environment. With respect to the idea that humans are subject to the laws of nature despite their special abilities, they neither disagreed nor agreed with the mean value of 3.90. However, most of the respondents agreed that plants and animals have as much right as humans to exist. This has a mean value of 4.28. This can be construed as ecocentric attitude inasmuch as they view the environment to be as important as the human beings. 


\section{Objective 2. To find out the environmental attitude of students at the LDCU main campus}

Table 2. Frequencies and Mean Values of Environmental Attitudes of College Instructors at the LDCU Main Campus

\begin{tabular}{|c|c|c|c|c|c|c|c|c|}
\hline \multirow[b]{2}{*}{ Questions } & \multicolumn{5}{|c|}{ Frequency } & \multirow[b]{2}{*}{ Total } & \multirow[b]{2}{*}{$\mathbf{x}$} & \multirow[b]{2}{*}{$\begin{array}{l}\text { Descriptive } \\
\text { Measures }\end{array}$} \\
\hline & $\begin{array}{c}\text { Strongly } \\
\text { Disagree } \\
1\end{array}$ & $\begin{array}{c}\text { Disagree } \\
2\end{array}$ & $\begin{array}{c}\text { Neither } \\
\text { Agree } \\
\text { Nor } \\
\text { Disagree } \\
3\end{array}$ & $\begin{array}{c}\text { Agree } \\
4\end{array}$ & $\begin{array}{c}\begin{array}{c}\text { Strongly } \\
\text { Agree }\end{array} \\
5\end{array}$ & & & \\
\hline $\begin{array}{l}\text { 1. One of the best things } \\
\text { about recycling is that it } \\
\text { saves money. }\end{array}$ & 1 & 1 & 0 & 14 & 53 & 69 & 4.69 & $\begin{array}{l}\begin{array}{c}\text { Strongly } \\
\text { Agree }\end{array} \\
\text { Ego } \\
\end{array}$ \\
\hline $\begin{array}{l}\text { 2. Nature is important } \\
\text { because of what it can } \\
\text { contribute to the } \\
\text { pleasure and welfare of } \\
\text { humans. }\end{array}$ & 0 & 1 & 0 & 14 & 54 & 69 & 4.77 & $\begin{array}{l}\text { Strongly } \\
\text { Agree } \\
\text { Ego }\end{array}$ \\
\hline $\begin{array}{l}\text { 3. One of the most } \\
\text { important reasons to } \\
\text { keep lakes and rivers } \\
\text { clean is so that people } \\
\text { have a place to enjoy } \\
\text { water sports. }\end{array}$ & 2 & 10 & 4 & 23 & 30 & 69 & 4.00 & $\begin{array}{l}\text { Agree } \\
\text { Ego }\end{array}$ \\
\hline $\begin{array}{l}\text { 4. The benefits of } \\
\text { modern consumer } \\
\text { products are more } \\
\text { important than the } \\
\text { pollution that results } \\
\text { from their production } \\
\text { and use. }\end{array}$ & 32 & 13 & 3 & 8 & 13 & 69 & 2.38 & $\begin{array}{l}\text { Neither agree } \\
\text { nor disagree }\end{array}$ \\
\hline $\begin{array}{l}\text { 5. Nature } \\
\text { primarily forists } \\
\text { use. }\end{array}$ & 9 & 5 & 9 & 17 & 29 & 69 & 3.75 & $\begin{array}{l}\text { Agree } \\
\text { Ego }\end{array}$ \\
\hline $\begin{array}{l}\text { 6. It makes me sad to } \\
\text { see natural } \\
\text { environments destroyed. }\end{array}$ & 0 & 0 & 0 & 5 & 64 & 69 & 4.92 & $\begin{array}{c}\text { Strongly } \\
\text { agree } \\
\text { Eco }\end{array}$ \\
\hline $\begin{array}{l}\text { 7. Nature is valuable for } \\
\text { its own sake. }\end{array}$ & 9 & 3 & 5 & 17 & 35 & 69 & 4.00 & $\begin{array}{l}\text { Agree } \\
\text { Eco }\end{array}$ \\
\hline $\begin{array}{l}\text { 8. Humans have the } \\
\text { right to damage the } \\
\text { environment just to get } \\
\text { greater economic } \\
\text { growth. }\end{array}$ & 54 & 5 & 0 & 1 & 3 & 69 & 1.2 & $\begin{array}{c}\text { Strongly } \\
\text { Disagree } \\
\text { Eco }\end{array}$ \\
\hline $\begin{array}{l}\text { 9. Despite our special } \\
\text { abilities, humans are } \\
\text { subject to the laws of } \\
\text { nature }\end{array}$ & 5 & 4 & 1 & 20 & 39 & 69 & 4.22 & $\begin{array}{l}\text { Agree } \\
\text { Eco }\end{array}$ \\
\hline $\begin{array}{l}\text { 10. Plants and animals } \\
\text { have as much right as } \\
\text { humans to exist. }\end{array}$ & 3 & 0 & 3 & 17 & 46 & 69 & 4.49 & $\begin{array}{c}\text { Agree } \\
\text { Eco }\end{array}$ \\
\hline
\end{tabular}


Table 2 presents the frequencies and mean values of environmental attitudes of the college instructors. It can be gleaned from the table that majority of the respondents have expressed their strong agreement on most of the items determining environmental attitudes from an ecocentric standpoint.

On the aspect of recycling that saves money, a mean value of 4.69 indicated a strong agreement on the part of the instructors which is from an egocentric perspective. As to the importance of nature to pleasure and welfare of humans, a mean value of 4.77 also expressed a strong agreement from an egocentric perspective. On the third item "reason to keep rivers and lakes clean to enjoy water sports" generated a mean value of 4.00 indicating agreement from the respondents.

Objective 3. To compare the environmental attitude of the college instructors and students at the LDCU main campus

Table 3. Comparison of the Descriptive Measures of Environmental Attitudes between College Instructors and Students

\begin{tabular}{|c|c|c|c|c|}
\hline \multicolumn{1}{|c|}{ Questions } & $\mathrm{X}$ & Descriptive Measures & $\mathrm{X}$ & Descriptive Measures \\
\hline $\begin{array}{l}\text { 1. One of the best } \\
\text { things about recycling } \\
\text { is that it saves money. }\end{array}$ & 4.69 & $\begin{array}{c}\text { Strongly } \\
\text { Agree }\end{array}$ & 4.37 & Agree \\
\hline $\begin{array}{l}\text { 2. Nature is important } \\
\text { because of what } \\
\text { it can contribute } \\
\text { to the pleasure } \\
\text { and welfare of } \\
\text { humans. }\end{array}$ & 4.77 & $\begin{array}{c}\text { Strongly } \\
\text { Agree }\end{array}$ & 4.47 & Agree \\
\hline $\begin{array}{l}3 . \text { One of the most } \\
\text { important reasons to } \\
\text { keep lakes and rivers } \\
\text { clean is so that people } \\
\text { have a place to enjoy } \\
\text { water sports. }\end{array}$ & 4.00 & Ego & Aggree & Agree \\
\hline $\begin{array}{l}\text { 4. The benefits of } \\
\text { modern consumer } \\
\text { products are more } \\
\text { important than the } \\
\text { pollution that results } \\
\text { from their production } \\
\text { and use. }\end{array}$ & 2.38 & Ego & 3.54 & Ego \\
\hline $\begin{array}{l}\text { 5. Nature exists } \\
\text { primarily for human } \\
\text { use. }\end{array}$ & $\mathbf{3 . 7 5}$ & $\begin{array}{c}\text { Agree } \\
\text { Ego }\end{array}$ & $\mathbf{3 . 3 9}$ & Neither agree nor disagree \\
\hline
\end{tabular}




\begin{tabular}{|l|c|c|c|c|}
\hline $\begin{array}{l}\text { 6. It makes me sad to } \\
\text { see natural } \\
\text { environments } \\
\text { destroyed. }\end{array}$ & 4.92 & $\begin{array}{c}\text { Strongly agree } \\
\text { Eco }\end{array}$ & 4.64 & $\begin{array}{c}\text { Strongly agree } \\
\text { Eco }\end{array}$ \\
\hline $\begin{array}{l}\text { 7. Nature is valuable } \\
\text { for its own sake. }\end{array}$ & 4.00 & $\begin{array}{c}\text { Agree } \\
\text { Eco }\end{array}$ & 3.91 & Neither agree nor disagree \\
\hline $\begin{array}{l}\text { 8. Humans have the } \\
\text { right to damage the } \\
\text { environment just to } \\
\text { get greater economic } \\
\text { growth. }\end{array}$ & 1.2 & $\begin{array}{c}\text { Strongly } \\
\text { Disagree }\end{array}$ & 1.60 & $\begin{array}{c}\text { Disagree } \\
\text { Eco }\end{array}$ \\
\hline $\begin{array}{l}\text { 9. Despite our special } \\
\text { abilities, humans are } \\
\text { subject to the laws of } \\
\text { nature }\end{array}$ & 4.22 & Eco & Agree \\
\hline $\begin{array}{l}10 \text { Plants and } \\
\text { animals have as much } \\
\text { right as humans to } \\
\text { exist. }\end{array}$ & 4.49 & $\begin{array}{c}\text { Agree } \\
\text { Eco }\end{array}$ & 4.28 & Neither agree nor disagree \\
\hline
\end{tabular}

Table 3 shows the comparison of the descriptive measures for each item between college instructors and students. Results show that there are more 'stronger agreements' from the teachers than from the students indicating that they exhibit stronger environmental attitude. Out of the ten (10) items in the survey questionnaire, four (4) responses expressed neutrality indicating a lack of awareness and environmental concern. This may imply that students have a low degree of connectedness to the environment. Their agreements equally come from both ecocentric and egocentric standpoints.

\section{CONCLUSIONS}

The college instructors exhibited a stronger environmental attitude indicating stronger connectedness to the environment. On the other hand, the college students exhibited weaker environmental attitude and regard it for their own benefit. The college instructors regard the environment more from the ecocentric standpoint while the students view it equally from both ecocentric and egocentric perspective indicating lack of awareness on environmental concerns and issues. 


\section{RECOMMENDATIONS}

1. There should be more efforts towards intensifying both students' and instructors' environmental awareness through more extensive Education Campaign, symposia and seminars. School ordinances should be created to promote discipline on waste disposal.

Management Implication

2. The institution should create an environmental committee to focus on the strict implementation of the provisions of Republic Act 9003 (Solid Waste Management Act in the campus. This should be delegated to subcommittees in each college. The committee should come up with project for each subcommittee to work on (recycling, segregating, etc.) by actually installing bins.

3. It is recommended that future researchers should replicate this research to monitor the environmental attitude of the students especially the next batch of students.

\section{LITERATURE CITED}

Chapman, D. \& Sharma, K. (2001). Environmental attitudes and behavior of primary and secondary students in Asian cities: An overview strategy for implementing an eco-schools programme. Environmentalist, 21: 265- 272. DOI: 10.1023/A: 1012996016601 environmental behaviors in Seventh grade students. J. Environ. Educ., 20: 29-34. DOI:10.1080/00958964.1989.9943036

Franzen, A. \& Meyer, R. (2010). Environmental attitudes in cross-national perspective: A multilevel analysis of the ISSP 1993 and 2000. European Sociological Review, 26(2), 219-234.

Gatersleben, B., I. Steg, \& C. Vlek (2002). Measurement and determinants of environmentally significant consumer behavior. Environmental behavior, 34: 335-362. DOI: 10.1177/0013916503251466

Meinhold, J.L. \& A.J. Malkus (2005). Adolescent environmental behaviors: Can knowledge, attitudes and self-efficacy make a difference. Environ. Behav., 37: 511-532. DOI: 10.1177/0013916504269665 
Ramsey, J.E. \& H.R. Hugerford (1989). The effects of issue investigation and action training on significant consumer behavior. Environ. Behav. Stapp, W. (1978). An instructional model for environmental education. Prospects, 8: 495-507.

Steg, L. \& Vlek, C. (2009). Encouraging pro-environmental behaviour: An integrative review and research agenda. Journal of Environmental Psychology, 29, 309-317.

Tantawi, P. et al., (2007). Attitude towards the environment: An empirical investigation on Egyptian consumers. Online cscanada. net/index.php/mse/article/view/1273/1348

Thornton, A. (2009). Public attitudes and behaviours towards the environment - Tracker Survey: A report to the Department for Environment, Food and Rural Affairs, TNS, London.

Tilbury, D. (1994). The critical learning years for environmental education. In: environmental education. In: environmental education at the early childhood level, wilson, R.A. (Ed.). Washington, D.C. North American Association for Environmental Education, pp: 11-13

Uyeki, U.S. \& L.J. Holland (2000). Diffusion of proenvironment attitudes. Am. Behav. Sci.

Wilson, R.A. (1994). Environmental education at the early childhood level. 1st Edn., North American Association for Environmental Education, Washington, DC., ISBN:1884008143, pp: 126.

Vining, J. \& A. Ebreo (1992). Predicting recycling behavior from global and specific environmental attitudes and changes in recycling opportunities. Journal of Applied Social Psychology, 22: 1580-1607. doi:0.1111/j.1559-1816 